\title{
PENENTUAN KEBUTUHAN KADAR PROTEIN PAKAN UNTUK PERTUMBUHAN DAN SINTASAN BENIH IKAN JELAWAT (Leptobarbus hoeveni)
}

\author{
Ningrum Suhenda*) dan Evi Tahapari*)
}

\begin{abstract}
ABSTRAK
Informasi tentang kebutuhan nutrien benih ikan jelawat diperlukan dalam usaha pem. benihannya. Suatu percobaan dengan tujuan untuk mengetahui kebutuhan kadar protein dalam pakan benih ikan jelawat sebagai data dasar guna pembuatan formulasi pakan untuk benih ikan omnivora telah dilakukan di laboratorium nutrisi, Sukamandi. Rancangan percobaan yang dipergunakan adalah Rancangan Acak Lengkap dengan 5 perlakuan dan 4 ulangan. Pakan uji yang diberikan adalah pakan yang mengandung protein sebesar $25 \%, 30 \%, 35 \%, 40 \%$ dan $45 \%$. Kandungan energi masing-masing pakan sama, yaitu $2700 \mathrm{~K} . \mathrm{kal} \mathrm{DE} / \mathrm{kg}$ pakan. Pakan diberikan dalam bentuk remah sebanyak $5 \%$ dari bobot total ikan per hari untuk 2 minggu ke-1; 4,5\% untuk 2 minggu ke-2 dan $4 \%$ dari bobot tubuh untuk 2 minggu ke- 3 dan ke-4. Penyesuaian jumlah pakan yang diberikan dilakukan tiap 2 minggu setelah dilakukan penimbangan ikan. Wadah penelitian yang dipergunakan, adalah akuarium dengan volume $70 \mathrm{~L}$ dan setiap akuarium dilengkapi dengan aerator. Ikan uji yang dipergunakan, adalah benih ikan jelawat dengan bobot rata-rata 6,7 g/ekor. Padat penebaran tiap akuarium, yaitu 50 ekor per akuarium.
\end{abstract}

Hasil percobaan menunjukkan bahwa pakan dengan kadar protein berbeda memberikan kurva respon yang kuadratik untuk parameter laju pertambahan bobot harian, pertambahan bobot rata-rata individu, konversi pakan, retensi protein dan retensi lemak. Nilai maksimum laju pertambahan bobot harian 1,98\%; pertambahan bobot rata-rata individu $12,03 \mathrm{~g}$ dan retensi lemak $66,01 \%$ diperoleh pada pakan dengan kadar protein masing-masing $40,21 \%, 40,58 \%$ dan $40,95 \%$. Konversi pakan terbaik, yaitu 1,79 diperoleh pada pakan dengan kadar protein $40,22 \%$. Retensi protein maksimum $(32,43 \%)$ diperoleh pada ikan yang diberi pakan dengan kadar protein $29,29 \%$. Sintasan benih ikan jelawat $(98,5-100 \%)$ tidak berbeda nyata antar perlakuan. Pakan dengan kadar protein $40,21-40,58 \%$ dan energi $2700 \mathrm{~K} . \mathrm{kal} \mathrm{DE} / \mathrm{kg}$ pakan memberikan pengaruh yang terbaik untuk pertumbuhan benih ikan jelawat.

\section{ABSTRACT: Effect of dietary protein levels on the growth and survival rate of Leptobarbus hoeveni fingerlings. By: Ningrum Suhenda and Evi Tahapari.}

An experiment was conducted to evaluate the effect of different levels of dietary protein on the growth and survival rate of Leptobarbus hoeveni fingerlings. Fifty fingerlings averaging $6.7 \mathrm{~g}$ individual body weight were stocked in each of 20 aquariums filled with 70 liters of water. They were fed daily for eight weeks with diets containing $25 \% ; 30 \% ; 35 \% ; 40 \%$; and $45 \%$ protein each equal to $2,700 \mathrm{~K}$.cal DE $/ \mathrm{kg}$ of feed. The feed was given in crumble form at $5 \%$ of body weight for the first two weeks, $4.5 \%$ for the following two weeks, and $4 \%$ for the last four weeks.

The result showed that feeds with different protein content gave quadratic respond curve. Maximum values for daily growth rate (1.98\%); individual weight gain (12.03 g); protein retention $(32.43 \%)$ and lipid retention (66.01\%) were obtained with feed containing $40.21 \% ; 40.58 \% ; 29.28 \%$; and $40.95 \%$ protein, respectively. The feed with $40.22 \%$ protein content gave the best feed conversion (1.79). Survival rates were not different among treatments (98.5-100\%).

It is sugested that feed with protein content between $40.21 .40 .58 \%$ and $2,700 \mathrm{~K}$.cal DE/kg of feed can be used in intensive culture of Leptobarbus hoeveni fingerlings to attain the best growth and survival rate.

\section{KEYWORDS: Fish nutrition; Leptobarbus hoeveni; fish feed.}

Peneliti pada Balai Penelitian Perikanan Air Tawar, Sukamandi 


\section{PENDAHULUAN}

Pengembangan budidaya ikan, baik ikan karnivora, omnivora maupun herbivora dapat dilaksanakan apabila aspek makanan untuk ketiga jenis ikan tersebut diketahui atau dikuasai. Aspek makanan terutama sekali mengenai kebutuhan nutrien sangat perlu diketahui karena dengan adanya data atau informasi kebutuhan nutrien maka formulasi pakan yang tepat dapat dibuat dengan berpedoman pada informasi atau data kebutuhan nutrien dan mutu bahan makanan yang digunakan.

Kebutuhan nutrien yang perlu diketahui antara lain protein, lemak, karbohidrat, vitamin dan mineral. Protein merupakan zat makanan yang sangat dibutuhkan untuk pemeliharaan tubuh. pembentukan jaringan, penggantian jaringan-jaringan tubuh yang rusak, serta penambahan protein tubuh dalam proses pertumbuhan (Cowey dan Sargent, 1972). Selanjutnya, Halver et al. (1973) menyatakan bahwa protein merupakan bagian terbesar dari daging ikan. Oleh karena itu, dalam menentukan kebutuhan nutrisi, kebutuhan protein perlu dipenuhi terlebih dahulu.

Protein juga dapat digunakan sebagai sumber energi seperti halnya lemak dan karbohidrat. Mengingat harga protein relatif lebih mahal dibandingkan dengan lemak dan karbohidrat, maka protein diusahakan dimanfaatkan hanya untuk pertumbuhan dan penggantian jaringan yang rusak (Lovell, 1988). Ogino dan Saito (1970) menyatakan bahwa kebutuhan protein benih ikan mas dengan bobot awal $5 \mathrm{~g}$ adalah sebesar $38 \%$.

Pada usaha budidaya intensif, biaya produksi yang terbesar $( \pm 60-65 \%)$ adalah biaya untuk pengadaan pakan. Untuk mencapai tujuan (sasaran) pembangunan pertanian, yaitu peningkatan pendapatan petani, maka pakan dengan formulasi yang tepat, bermutu tinggi, efisien dan ekonomis perlu diperoleh.

Ikan jelawat (Leptobarbus hoeveni) sebagai ikan omnivora merupakan salah satu jenis ikan asli perairan umum Indonesia yang terdapat di sungai-sungai di Sumatera dan Kalimantan. Ikan ini termasuk jenis ikan ekonomis penting yang sangat digemari masyarakat setempat maupun negara tetangga seperti Malaysia. Peningkatan permintaan pasar telah merangsang pengembangan budidaya jenis ikan ini baik ukuran benih maupun konsumsi. Selama ini, produksi ikan jelawat masih mengandalkan hasil tangkapan dari alam sehingga dapat mengancam kelestariannya. Dengan berkembangnya budidaya maka faktor makanan harus mendapat perhatian. Hasil percobaan pemberikan pakan buatan berupa pelet untuk ikan jelawat menunjukkan bahwa protein, lemak dan karbohidrat yang dikandung tepung ikan dicerna $100 \%$ sedangkan protein, lemak dan karbohidrat yang dikandung bungkil kedelai hanya dicerna berturut-turut sebesar 69,50\%; 60,70\%; dan 73,82\% (Law, 1984).

Informasi tentang kebutuhan nutrien ikan jelawat belum banyak diperoleh karena ikan ini adalah ikan asli perairan umum yang usaha budidayanya belum berkembang. Upaya domestikasi ikan jelawat telah dilakukan dan ikan ini dapat dipijahkan dengan teknik hipofisasi (Hardjamulia dan Atmawinata, 1986). Kemudian teknik ini dikembangkan di Balai Benih Ikan di Kalimantan Barat dan berhasil memproduksi benih (Hardjamulia et al., 1992).

Tujuan penelitian yang dilakukan yaitu untuk mengetahui kebutuhan kadar protein dalam pakan benih ikan jelawat dan untuk memperoleh salah satu data dasar guna pembuatan formulasi pakan untuk benih ikan omnivora.

\section{BAHAN DAN METODE}

Penelitian ini dilakukan selama 8 minggu di laboratorium nutrisi Balai Penelitian Perikanan Air Tawar Sukamandi, Subang. Ikan yang dipergunakan, yaitu benih ikan jelawat (Leptobarbus hoeveni) dengan bobot antara 6,2-7,6 g (rata-rata $6,7 \mathrm{~g} / \mathrm{ekor}$ ) yang diperoleh dari petani ikan di Jambi, Sumatera. Percobaan dilakukan dengan menggunakan akuarium yang berisi air sumur sebanyak $70 \mathrm{~L}$ dan dilengkapi dengan aerator. Sebelum digunakan, air ditampung dalam bak penampungan dan diaerasi. Benih ikan dimasukkan dengan padat penebaran 50 ekor/akuarium. Adaptasi ikan baik terhadap lingkungan maupun pakan dilakukan selama 10 hari. Penggantian air sebanyak $80 \%$ dari masing-masing akuarium dilakukan pada pagi dan sore hari. Pada waktu penggantian air dilakukan penyedotan kotoran yang ada pada masing-masing akuarium.

Rancangan percobaan yang digunakan adalah Rancangan Acak Lengkap (RAL) dengan lima perlakuan, yaitu pakan dengan kandungan 
berbeda $(25,30,35,40$ dan $45 \%)$ dan 4 ulangan. Kandungan energi masing-masing pakan sama, yaitu sebesar $2.700 \mathrm{Kkal} \mathrm{DE} / \mathrm{kg}$ pakan.

Pakan dibuat dan dianalisis di Balai Penelitian Perikanan Air Tawar Sukamandi. Sebelum pakan dibuat, bahan makanan yang digunakan dianalisis secara proksimat. Pakan diberikan dalam bentuk remah sebanyak $5 \%$ dari bobot tubuh untuk 2 minggu ke-1; 4,5\% untuk 2 minggu ke- 2 ; dan $4 \%$ dari bobot tubuh untuk 2 minggu ke-3 dan ke-4. Penyesuaian jumlah pakan yang diberikan dilakukan tiap 2 minggu setelah dilaksanakan penimbangan ikan (sampling). Pakan diberikan dengan cara ditebar secara manual 3 kali sehari, yaitu pada pukul 08.00, 12.00 dan pukul 16.00. Komposisi pakan percobaan tertera pada Tabel 1.
Penimbangan ikan dilakukan 2 minggu sekali dengan menggunakan timbangan $\mathrm{O}$-Haus dengan ketelitian 0,1 g. Penimbangan ikan dilakukan dalam keadaan basah dengan cara memasukkan ikan ke dalam wadah plastik yang berisi air. Ikan yang mati selama penelitian, ditimbang dan dicatat bobot dan jumlahnya. Pada waktu penghitungan akhir, data tersebut dimasukkan ke dalam perhitungan produksi dan konversi pakan. Pengukuran sifat fisika kimia air, yaitu suhu, $\mathrm{pH}$, $\mathrm{O}_{2}, \mathrm{CO}_{2}$, alkalinitas, amonia dan nitrit dilakukan pada pukul 08.00 setiap waktu sampling.

Parameter yang diamati meliputi laju pertambahan bobot harian, pertambahan bobot ratarata individu, konversi pakan, sintasan, retensi protein dan retensi lemak. Respon masing-masing parameter terhadap perlakuan dilakukan dengan menggunakan uji F.

Tabel 1. Komposisi 5 pakan percobaan dengan kadar protein yang berbeda.

Table 1. Composition of 5 experimental diets containing different protein levels.

\begin{tabular}{|c|c|c|c|c|c|}
\hline \multirow{2}{*}{$\begin{array}{c}\text { Bahan makanan (\%) } \\
\text { Ingredient }(\%)\end{array}$} & \multicolumn{5}{|c|}{ Jenis pakan (Diets) } \\
\hline & $\mathrm{A}(25 \%)^{*}$ & B $(30 \%)^{*}$ & C $(35 \%)^{*}$ & D $(40 \%)^{*}$ & E $(45 \%)^{*}$ \\
\hline $\begin{array}{l}\text { Tepung ikan } \\
\text { Fish meal }\end{array}$ & 20 & 25 & 31 & 36 & 41 \\
\hline $\begin{array}{l}\text { Bungkil kedelai } \\
\text { Soybean meal }\end{array}$ & 17 & 22 & 26 & 30 & 35 \\
\hline $\begin{array}{l}\text { Dedak halus } \\
\text { Rice bran }\end{array}$ & 10 & 10 & 10 & 10 & 10 \\
\hline $\begin{array}{l}\text { Tapioka } \\
\text { Cassava flour }\end{array}$ & 39.6 & 29.9 & 20.4 & 11.4 & 1.7 \\
\hline $\begin{array}{l}\text { Vitamin } \\
\text { Vitamine premix }\end{array}$ & 2 & 2 & 2 & 2 & 2 \\
\hline $\begin{array}{l}\text { Mineral } \\
\text { Mineral premix }\end{array}$ & 1 & 1 & 1 & 1 & 1 \\
\hline $\begin{array}{l}\text { Minyak ikan } \\
\text { Fish oil }\end{array}$ & 2.25 & 2.0 & 1.75 & 1.50 & 1.25 \\
\hline $\begin{array}{l}\text { Minyak jagung } \\
\text { Corn oil }\end{array}$ & 2.25 & 2.0 & 1.75 & 1.50 & 1.25 \\
\hline $\begin{array}{l}\text { Bahan pengisi filler } \\
\text { Lignobon }\end{array}$ & 5.90 & 6.10 & 6.10 & 6.60 & 6.80 \\
\hline
\end{tabular}

*) Kadar protein pakan (protein content of the diets) 


\section{HASIL DAN PEMBAHASAN}

\section{Pertumbuhan}

Hasil penelitian menunjukkan bahwa perbedaan kadar protein pakan memberikan laju pertambahan bobot harian benih ikan jelawat yang berbeda sangat nyata $(P<0,01)$. Laju pertambahan bobot harian benih jelawat yang diberi pakan dengan kadar protein $25 \%$ paling rendah, yaitu $1,55 \%$ dan berbeda nyata dengan laju pertambahan bobot ikan yang diberi pakan dengan kadar protein 30 ; 35; 40; dan $45 \%$. Pada kisaran protein antara $25-45 \%$, kadar protein pakan memberikan respon kuadratik terhadap laju pertambahan bobot harian mengikuti persamaan: $y=-1,093+0,1528 x-0,0019 x^{2} ;$ yang artinya laju pertambahan bobot harian meningkat dengan meningkatnya kadar protein pakan hingga mencapai nilai maksimum sebesar $1,98 \%$ pada kadar protein pakan $40,21 \%$, setelah itu laju pertambahan menurun walaupun kadar protein ditingkatkan.
Perbedaan kadar protein pakan memberikan perbedaan pertambahan bobot rata-rata individu benih ikan jelawat $(P<0,05)$ kecuali antara pakan yang mengandung protein $40 \%$ dengan $45 \%$ (Tabel 2). Ikan yang diberi pakan dengan kadar protein $25 \%$ memberikan pertambahan bobot paling rendah, yaitu $8,21 \mathrm{~g}$. Pada kisaran protein antara $25-45 \%$, kadar protein pakan memberikan respon kuadratik terhadap pertambahan bobot rata-rata individu mengikuti persamaan $\mathrm{y}=$. $14,1551+1,2904 \mathrm{x}-0,0159 \mathrm{x}^{2} ;$ yang artinya pertambahan bobot rata-rata individu meningkat dengan meningkatnya kadar protein pakan hingga mencapai nilai maksimum sebesar 12,03 g pada kadar protein pakan $40,58 \%$ setelah itu pertambahan bobot menurun walaupun kadar protein pakan ditingkatkan. Bobot rata-rata individu ikan per perlakuan untuk setiap waktu pengamatan tertera pada Gambar 1. Pada Gambar 1 dapat dilihat bahwa bobot tubuh ikan yang diberi pakan dengan kadar protein $25 \%$ paling rendah dan berbeda dengan perlakuan lainnya. Bobot akhir ikan yang dipelihara dalam akuarium dan diberi pakan dengan kadar protein $40 \%$ yaitu 18,94 g atau 2,83 kali lipat bobot awal.

Tabel 2. Laju pertambahan bobot harian (\%) dan pertambahan bobot rata-rata individu (g) benih ikan jelawat selama 8 minggu pemeliharaan.

Table 2. Daily growth rate (\%) and average individual weight gain (g) of Leptobarbus hoeveni during 8 weeks rearing period.

\begin{tabular}{ccc}
\hline $\begin{array}{c}\text { Perlakuan/Kadar protein } \\
\text { pakan (Treatments/Protein } \\
\text { content of the feeds) } \\
(\%)\end{array}$ & $\begin{array}{c}\text { Laju pertambahan bobot } \\
\text { harian (Daily growth rate) }\end{array}$ & $\begin{array}{c}\text { Pertambahan bobot mutlak } \\
\text { rata-rata (Average } \\
\text { individual weight gain) } \\
\text { (g) }\end{array}$ \\
\hline 25 & $(\%)$ & $8.21^{\mathrm{a}}$ \\
30 & $1.55^{\mathrm{a}}$ & $10.15^{\mathrm{b}}$ \\
35 & $1.79^{\mathrm{b}}$ & $11.34^{\mathrm{bc}}$ \\
40 & $1.92^{\mathrm{bc}}$ & $12.24^{\mathrm{c}}$ \\
45 & $2.01^{\mathrm{c}}$ & $11.54^{\mathrm{c}}$ \\
\hline
\end{tabular}

Nilai rata-rata pada lajur dengan tanda huruf yang sama tidak berbeda nyata (Mean value in the column followed by the same superscript are not significantly different $)(\mathrm{P}>0.01)$ 

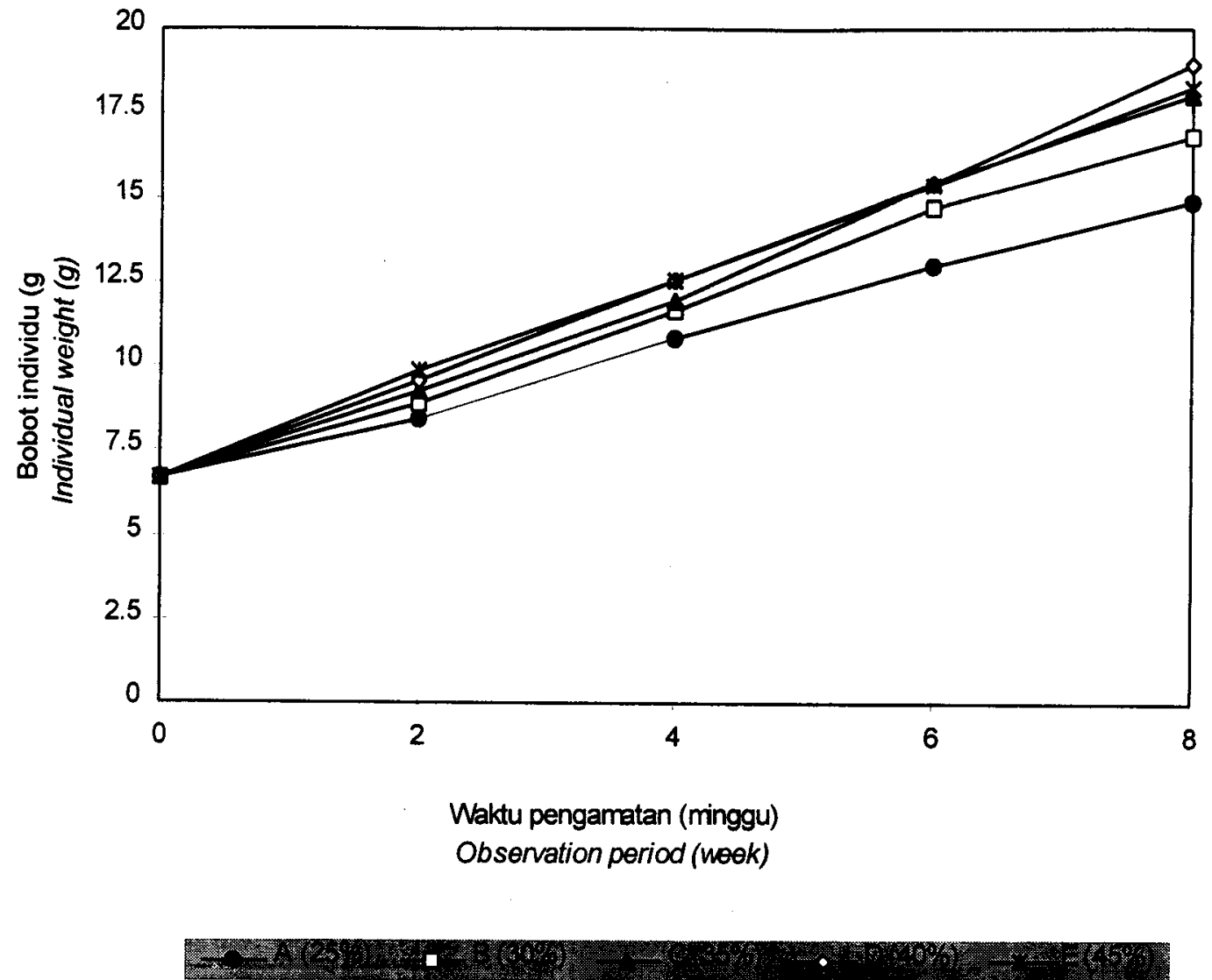

Gambar 1. Bobot rata-rata individu ikan per perlakuan setiap waktu pengamatan.

Figure 1. The average individual weight $g$ fish during observation period.

\section{Konversi Pakan}

Berdasarkan analisis ragam diperoleh bahwa pakan dengan kadar protein berbeda memberikan nilai konversi pakan yang berbeda nyata $(\mathrm{P}<0,05)$. Konversi pakan yang tertinggi $(2,38)$ diperoleh pada perlakuan pakan dengan kadar protein $25 \%$. Konversi pakan yang terbaik, yaitu 1,74 diperoleh pada ikan yang diberi pakan dengan kadar protein $40 \%$ (Tabel 3). Dari analisis polinom ortogonal diperoleh bahwa pada kisaran protein antara $25.45 \%$, kadar protein berbeda memberikan kurva respon yang kuadratik terhadap konversi pakan mengikuti persamaan $y=5,8392 \cdot 0,2011 x+0,0025 x^{2}$. Nilai konversi terbaik, yaitu sebesar 1,79 diperoleh pada pakan dengan kadar protein $40,22 \%$.

\section{Laju Sintasan}

Hasil analisis statistik menunjukkan bahwa laju sintasan benih ikan jelawat yang diberi pakan dengan kadar protein berbeda tidak berbeda nyata ( $P>0,05)$. Pada Tabel 4 dapat dilihat bahwa laju sintasan hidup benih ikan jelawat yang diberi pakan dengan kadar protein $40 \%$ mencapai $100 \%$. Untuk perlakuan lainnya terjadi mortalitas ikan uji walaupun jumlahnya relatif sedikit, yaitu berkisar antara $1-1,5 \%$. 
Tabel 3. Konversi pakan setiap perlakuan.

Table 3. Feed conversion for each treatments.

\begin{tabular}{cccccc}
\hline $\begin{array}{c}\text { Ulangan } \\
\text { Replications }\end{array}$ & \multicolumn{5}{c}{$\begin{array}{c}\text { Perlakuan/ kadar protein (\%) pakan } \\
\text { Treatments/protein content (\%) of the feeds }\end{array}$} \\
\hline & $\mathbf{2 5}$ & $\mathbf{3 0}$ & $\mathbf{3 5}$ & $\mathbf{4 0}$ & $\mathbf{4 5}$ \\
\hline 1 & 2.39 & 1.98 & 1.80 & 1.73 & 2.67 \\
2 & 2.23 & 2.11 & 1.74 & 1.60 & 1.88 \\
3 & 2.32 & 1.94 & 1.93 & 1.94 & 1.79 \\
4 & 2.56 & 2.03 & 2.14 & 1.67 & 1.61 \\
Rata-rata (Average) & $2.38^{\mathrm{c}}$ & $2.02^{\mathrm{b}}$ & $1.90^{\mathrm{ab}}$ & $1.74^{\mathrm{a}}$ & $1.84^{\mathrm{ab}}$ \\
\hline
\end{tabular}

Nilai rata-rata pada baris dengan tanda huruf yang sama tidak berbeda nyata (Mean value in the rows followed by the same superscript are not significantly different) $(\mathrm{P}>0.01)$

Tabel 4. Laju sintasan (\%) benih ikan jelawat (Leptobarbus hoeveni) untuk setiap perlakuan selama penelitian.

Table 4. Survival rates (\%) of Leptobarbus hoeveni for each treatments.

\begin{tabular}{cccccc}
\hline $\begin{array}{c}\text { Ulangan } \\
\text { Replications }\end{array}$ & \multicolumn{5}{c}{$\begin{array}{c}\text { Perlakuan/ kadar protein (\%) pakan } \\
\text { Treatments/protein content (\%) of the feeds }\end{array}$} \\
\hline & $\mathbf{2 5}$ & $\mathbf{3 0}$ & $\mathbf{3 5}$ & $\mathbf{4 0}$ & $\mathbf{4 5}$ \\
\hline 1 & 96 & 100 & 100 & 100 & 96 \\
2 & 100 & 98 & 100 & 100 & 100 \\
3 & 100 & 100 & 98 & 100 & 100 \\
4 & 100 & 96 & 98 & 100 & 98 \\
Rata-rata (Average) & $99^{\text {a }}$ & $98.5^{\text {a }}$ & $99^{\text {a }}$ & $100^{\text {a }}$ & $98.5^{\text {a }}$ \\
\hline
\end{tabular}

Nilai rata-rata pada baris dengan tanda huruf yang sama tidak berbeda nyata (Mean value in the rows followed by the same superscript are not significantly different $)(\mathrm{P}>0.01)$

\section{Retensi Protein dan Lemak}

Berdasarkan analisis ragam ternyata bahwa nilai retensi yang diperoleh pada benih ikan jelawat yang diberi pakan dengan perbedaan kadar protein berbeda nyata $(\mathrm{P}<0,05)$. Pakan dengan kadar protein 25 ; 30 ; dan $35 \%$ memberikan nilai retensi protein yang tidak berbeda tetapi berbeda nyata dengan nilai retensi yang diperoleh pada pakan dengan kadar protein $40 \%$ dan $45 \%$ (Tabel 5). Hasil analisis polinom orto- gonal diperoleh bahwa pada kisaran protein antara $25-45 \%$, kadar protein pakan yang berbeda memberikan kurva respon yang kuadratik terhadap retensi protein mengikuti persamaan $\mathrm{y}=$ $6,54+1,7686 x \cdot 0,0302 x^{2} ;$ yang artinya retensi protein meningkat dengan meningkatnya kadar protein pakan dan nilai retensi tertinggi $(32,43 \%)$ diperoleh pada pakan dengan kadar protein $29,28 \%$ setelah itu retensi protein menurun walaupun kadar protein pakan ditingkatkan. 
Tabel 5. Retensi protein (\%) dan retensi lemak (\%) benih ikan jelawat selama 8 minggu pemeliharaan. Table 5. Protein retention (\%) and lipid retention (\%) of Leptobarbus hoeveni during 8 weeks rearing period.

\begin{tabular}{ccc}
\hline $\begin{array}{c}\text { Perlakuan/Kadar protein } \\
\text { pakan (\%) }\end{array}$ & $\begin{array}{c}\text { Retensi protein (\%) } \\
\text { Protein rentention (\%) }\end{array}$ & $\begin{array}{c}\text { Retensi lemak (\%) } \\
\text { Lipid rentention (\%) } \\
\text { of the feeds (\%) }\end{array}$ \\
\hline 25 & $31.28^{\mathrm{a}}$ & \\
\hline 30 & $33.88^{\mathrm{a}}$ & $56.13^{\mathrm{a}}$ \\
35 & $30.52^{\mathrm{a}}$ & $65.75^{\mathrm{ab}}$ \\
40 & $28.63^{\mathrm{ab}}$ & $65.27^{\mathrm{ab}}$ \\
45 & $25.32^{\mathrm{b}}$ & $67.06^{\mathrm{b}}$ \\
\hline
\end{tabular}

Nilai rata-rata pada lajur dengan tanda huruf yang sama tidak berbeda nyata (Mean value in the columns followed by the same superscript are not significantly different $)(\mathrm{P}>0.01)$

Hasil analisis statistik menunjukkan bahwa pakan dengan kadar protein berbeda menghasilkan nilai retensi lemak yang berbeda nyata $(\mathrm{P}<0,05)$. Nilai retensi lemak pakan dengan kadar protein $40 \%(67,06 \%)$ tidak berbeda dengan pakan yang mengandung protein $45 \%(68,14 \%)$ tetapi berbeda dengan pakan yang mengandung protein sebesar $25 \%$ (Tabel 5). Pada kisaran protein antara $25-45 \%$, kadar protein pakan memberikan kurva respon kuadratik terhadap retensi lemak mengikuti persamaan $\mathrm{y}=40,95+$ $3,4646 x-0,0423 x^{2}$; yang artinya retensi lemak meningkat dengan meningkatnya kadar protein pakan dan mencapai nilai maksimum $(66,01 \%)$ pada kadar protein pakan $40,95 \%$ setelah itu retensi lemak yang diperoleh menurun walaupun kadar protein pakan ditingkatkan.

\section{Sifat Fisika Kimia Air}

Sebagai data penunjang, hasil pengukuran beberapa parameter sifat fisika kimia air selama penelitian adalah sebagai berikut:

$$
\begin{array}{lll}
\text { Suhu } & : & 25-29^{\circ} \mathrm{C} \\
\mathrm{pH} & : & 7,5 \\
\mathrm{DO} & : & 4,13-6,58 \mathrm{mg} / \mathrm{L} \\
\mathrm{CO}_{2} & : & 5,19-7,59 \mathrm{mg} / \mathrm{L} \\
\text { Alkalinitas } & : & 86,79-102,36 \mathrm{mg} / \mathrm{L} \mathrm{CaCO}_{3} \text { setara } \\
\text { Amonia } & : & 0,014-0,464 \mathrm{mg} / \mathrm{L} \\
\text { Nitrit } & : & 0,098-0,377 \mathrm{mg} / \mathrm{L}
\end{array}
$$

Dari data tersebut ternyata kisaran sifat fisika kimia air masih ada dalam batas yang cukup baik untuk mendukung kehidupan dan pertumbuhan ikan uji.

Kualitas pakan, dalam hal ini kadar protein pakan berperan dalam menentukan hasil percobaan yang diperoleh. Protein dalam pakan mempengaruhi besarnya laju pertambahan bobot harian, pertambahan bobot individu, konversi pakan, retensi protein dan retensi lemak yang diperoleh.

Pakan dengan kadar protein $25 \%$ memberikan pertumbuhan yang paling rendah dan berbeda dengan pakan lainnya. Hal ini dapat dilihat pada Gambar 1, nilai laju pertambahan bobot harian $(1,55 \%)$ dan pertambahan bobot $(8,21 \mathrm{~g})$. Rendahnya pertumbuhan pada perlakuan ini diduga akibat rendahnya kadar protein dalam pakan sehingga tidak dapat mencukupi kebutuhan ikan untuk mendukung pertumbuhannya secara maksimal.

Selanjutnya, pengaruh protein terhadap pertumbuhan tidak dapat lepas dari faktor energi karena kedua faktor ini bekerja sama pada proses metabolisme. Walaupun kandungan energi semua pakan perlakuan sama tetapi kadar sumber energi yang berasal dari protein dan karbohidrat tidak sama sedangkan kadar lemak semua pakan 
percobaan sama. Untuk memenuhi kebutuhan energinya ikan yang diberi pakan dengan kadar protein $25 \%$ akan merombak lemak dan karbohidrat yang dikandungnya. Menurut Fleisher et al. (1962) apabila terjadi perombakan lemak maka kandungan essential fatty acids (EFA) akan berkurang. Kekurangan EFA akan menyebabkan perubahan permeabilitas membran sel dan perubahan ini sangat dipengaruhi oleh fosfolipid. Perubahan permeabilitas yang tidak sesuai akan mengganggu aktivitas enzim-enzim yang terdapat pada membran mitokondria. Selanjutnya akan terjadi gangguan metabolisme energi sehingga proses sintesis protein pun terganggu dan akhirnya pertumbuhan yang diperoleh lebih rendah.

Pakan dengan kadar protein 25\% kadar karbohidratnya paling tinggi. Karbohidrat dapat mempengaruhi penggunaan protein. Karbohidrat sebesar $0,23 \mathrm{~g} / 100 \mathrm{~g}$ pakan dapat menggantikan (spare) protein sebesar 0,05 g namun penggunaannya terbatas. Penggunaan dekstrin yang tinggi (15-20\%) pada kerabat ikan lele akan menurunkan pertambahan bobot dibandingkan dengan hanya $2,5-10 \%$ (Wilson, 1977). Selain itu, menurut NRC (1977), kecernaan dekstrin $73 \%$ bila pakan mengandung dekstrin $30 \%$, dan akan menurun menjadi $48 \%$ bila pakan mengandung dekstrin sebesar $60 \%$.

Sebaliknya, ikan tidak mampu memanfaatkan pakan dengan kadar protein terlalu tinggi secara efisien disebabkan energi tubuh yang dikeluarkan untuk proses deaminasi (specific dynamic action) meningkat sehingga mengurangi energi untuk pertumbuhan dan akibatnya pertumbuhan ikan menjadi rendah (Jobling, 1985).

Pada percobaan ini, pakan dengan kadar protein $40 \%$ yang diberikan pada benih ikan jelawat dengan bobot awal 6,7 g/ekor dan padat penebaran 50 ekor/70L diperoleh laju pertambahan bobot harian sebesar 1,94\%; konversi pakan 1,74 ; retensi protein $28,63 \%$, dan bobot akhirnya mencapai $18,94 \mathrm{~g}$ atau $283 \%$ dari bobot awal. Pengaruh protein terhadap konversi pakan menunjukkan bahwa makin rendah kadar protein pakan makin tinggi konversi pakan yang diperoleh. Konversi pakan yang terbaik $(1,79)$ diperoleh pada pakan dengan kadar protein $40,22 \%$. Pertumbuhan yang tinggi baru ada artinya bila jumlah makanan yang diberikan seminimal mungkin. Untuk mencapai tujuan tersebut, makanan yang diberikan harus seefektif mungkin.

Pertumbuhan tidak dapat dipelajari tanpa melibatkan konsumsi makanan (Brett, 1979). Indikator yang digunakan NRC (1977) untuk menentukan efektivitas pakan adalah besar kecilnya nilai konversi atau efisiensi pakan. Tingginya konversi pakan menunjukkan efisiensi pakan yang rendah atau penggunaan pakan untuk pertumbuhan kurang efisien. Apabila dilihat dari nilai efisiensi pakan maka pakan dengan kadar protein $40 \%$ efisiensinya mencapai $57,47 \%$.

Pengaruh kadar protein pakan pada retensi protein memberikan respon yang kuadratik. Dengan naiknya kadar protein pakan, retensi protein cenderung naik dan sampai tercapai titik maksimum $(32,43 \%)$ pada kadar protein pakan sebesar $29,28 \%$ dan setelah itu menurun dan terendah dicapai pada pakan dengan kadar protein $45 \%$, yaitu $25,32 \%$.

Adanya kecenderungan naiknya retensi protein dengan naiknya kadar protein pakan karena protein memegang peranan penting dalam pembentukan struktur atau jaringan tubuh. Retensi protein menurun dengan semakin naiknya kadar protein pakan disebabkan secara proporsi protein yang digunakan untuk membentuk protein baru akan lebih rendah (NRC, 1983). Viola dan Rappaport (1979) menggunakan retensi protein sebagai indikator efektivitas pakan.

Pengaruh kadar protein pakan pada retensi lemak yang diperoleh adalah kuadratik. Nilai retensi lemak maksimum (66,01\%) diperoleh pada pakan dengan kadar protein $40,95 \%$. Retensi lemak yang diperoleh bukan merupakan retensi murni dari lemak pakan yang diberikan melainkan ada penambahan yang berasal dari karbohidrat dan protein karena kadar lemak setiap pakan uji sama besarnya. Jadi dalam hal ini retensi lemak juga diperoleh dari biokonversi karbohidrat dan protein.

\section{KESIMPULAN DAN SARAN}

Dari hasil penelitian yang dilakukan dapat diambil kesimpulan bahwa pakan dengan kadar protein antara $40,21-40,58 \%$ memberikan pengaruh yang terbaik untuk pertumbuhan benih ikan jelawat. 


\section{DAFTAR PUSTAKA}

Brett, J.R. 1979. Environmental factors and growth. In W.S. Hoar, D.J. Randall and J.R. Brett (Eds). Fish physiology, Vol. VIII. Acad. Press, London. p: 599 675

Cowey, C. B. and J. R. Sargent. 1972. Fish nutrition. Advances in Marine Biology. 10: 303-477

Fleisher, S., G. Brierly, H. Klouwen and D.B. Slautterback. 1962. Studies of the electron system. J. Biol. Chem., 237 (10) : 3264-3272.

Halver, J.E., J.A. Coats, C.W. De Yoe, H.K. Dupree, G. Post and R.O. Sinihuber. 1973. Nutrient requirements of trout. salmon and catfish. Nat. Acad.Sc., Washington D.C., Nat. Res. Counc. Comm. Anim, Nutr., Ser. No. 11. 57 p.

Hardjamulia, A dan S. Atmawinata. 1986. Teknik hipofisasi beberapa jenis ikan tawar. Dalam Fuad Cholik (Ed.) Pros. Lokakarya Nasional Teknologi Tepat Guna Bagi Pengembangan Perikanan Budidaya Air Tawar. Bogor 28 - 31 Juni 1980. Balai Penelitian Perikanan Air Tawar.

Hardjamulia, A. N. Suhenda. W. Ismail dan A. Priyadi. 1992. Teknologi pembenihan ikan jelawat (Leptobarbus hoeveni) secara terkontrol. Pusat Penelitian dan Pengembangan Perikanan. Jakarta.
Jobling. M. 1985. Growth. In P. Tytler (Ed). Fish Energetics. New Perspectives. Croom Helm, London. 349 p.

Law, A.T. 1984. Nutritional study of jelawat Leptobarbus hoevenii (Bleeker), fed on pelleted. Aquaculture. 41: 227-233.

Lovell, T. 1988. Nutrition and feeding on fish. New York, Van Nostrand Reinhold.

NRC. 1977. Nutrients requirements of warmwater fishes. National Academy of Sciences, Washington D.C., 78 p.

NRC. 1983. Nutrient requirement of warmwater fishes and shell-fishes. National Academy of Sciences. Washington D.C., 102 p.

Ogino, C. and K. Saito. 1970. The utilization of dietary protein by young carp. Bull. of Japan Soc. of Scient. Fish., 36 (3) : 250-255.

Viola, S. and U. Rappaport. 1979. The "extra calorie effect" of oil in nutrition of carp. Banidgeh, 31 (3) : $51 \cdot 69$.

Wilson, R.P. 1977. Carbohydrates in catfish nutrition. In R.R. Stickney and R.T. Lovel (Eds). Nutrition and feeding of Channel catfish. Southern Cooperative Series Bull., No 218. p: $19 \cdot 20$ 